\title{
DENDROCHRONOLOGICAL AND RADIOCARBON ANALYSIS OF THE BEAM FOUNDATION OF THE MEDIEVAL STONE WALL OF SZÉKESFEHÉRVÁR
}

\author{
EMIL HORVÁTH* - FRIGYES SZÜCSI** - ZOLTÁN KERN*** - ANDRÁS MORGÓS**** \\ * Kölcsey Ferenc u. 53. H-8051 Sárkeresztes, Hungary \\ emildendro@gmail.com \\ ** Jókai u. 3. H-8046 Bakonykúti, Hungary \\ szucsifrigyes@gmail.com \\ *** Institute for Geological and Geochemical Research, Research Centre for Astronomy and Earth Sciences, \\ Hungarian Academy of Sciences, \\ Budaörsi út 45, H-1112 Budapest, Hungary \\ kern.zoltan@csfk.mta.hu \\ $* * * *$ Consart, \\ Kálló esperes u. 1. H-1124 Budapest, Hungary \\ andrasmorgos@gmail.com
}

\begin{abstract}
In this paper the authors publish the results of the dendrochronological and radiocarbon investigation of the beam foundation excavated in the backyard of 20 Jókai Street under the medieval western town wall of Székesfehérvár. Based on the $11^{\text {th }}$ century dating results - hypothesizing the primary usage of the beams - they delineate the historical significance of the early stone town wall in medieval Europe and the Hungarian Kingdom.

Keywords: $11^{\text {th }}$ century beam foundation, town wall, stone wall, King Saint Stephen of Hungary, ${ }^{14} \mathrm{C}$ dating, dendrochronology, wiggle-matching
\end{abstract}

\section{INTRODUCTION}

Numerous wooden structures (piles and beams) have been collected from the excavations lead by Gyula Siklósi ${ }^{1}$ in the town of Székesfehérvár and stored at the Szent István Király Museum (King St. Stephen Museum). Investigation of these timbers applying state-of-art scientific methods (especially the determination of their age) could contribute novel information to knowledge of the medieval and early-modern (e.g. Ottoman Period) history and topography of the town which could hardly be acquired solely by traditional archaeological age determination methods.

\section{THE DATING QUESTION OF THE TOWN WALL OF FEHÉRVÁR ${ }^{2}$}

In the research history of the town wall of the medieval Fehérvár, archaeologists, historians and art historians have formed different views and opinions regarding the potential time of the building of the wall. A comprehensive early review by the historian Lajos Nagy stated "... we do not know the construction date of this wall exactly. Neither documentary, nor archaeological evidence is available assigning this date". At the same time an art historian, Péter Kovács, refrained from any statement on the construction date but noted that at the beginning of

${ }^{1}$ Expressing our respect and thanks, this study is dedicated to the memory of Dr. Gyula Siklósi (Budapest, 1949 - Székesfehérvár, 2017). As senior research fellow of the Hungarian Academy of Sciences, he was from 1978 until his death the foremost connoisseur of the medieval history of Székesfehérvár. In recognition of his work he was elected an honorary citizen of the city in 2012, and then he received the Knight's Cross of the Hungarian Order of Merit in 2014.

${ }^{2}$ The city of Székesfehérvár was mentioned first in Latin as Alba Civitas and Albensis Civitas in 1009, however, the first written form of the Hungarian name Fehérvár can be read in the founding DOI: $10.1556 / 072.2018 .69 .1 .7$ charter of the Tihany Abbey from 1055 (GYöRFFY 1987, 376; ZsOLDOS-THOROCZKAY-KISS 2016, 21). Based on the summary of Gy. Siklósi the Székesfehérvár name form of the town appeared only first in 1539 (SiKLósi 2013, 5), therefore we consequently call the town Fehérvár in this paper referring to the Middle Ages.

${ }^{3}$ Until then only Jenő Fitz, László Gerő and Alán Kralovánszky had taken a stand on the building date of the town wall, placing its construction most likely in the $14^{\text {th }}$ or the $15^{\text {th }}$ centuries, at the reign of King Charles Robert or King Sigismund of Luxemburg (NAGY 1972, 211).

Acta Archaeologica Academiae Scientiarum Hungaricae 69 (2018) 169-183 0001-5210 @ 2018 Akadémiai Kiadó, Budapest 
the $15^{\text {th }}$ century the town wall must have already been there. ${ }^{4} \mathrm{~A}$ decade later still the same, not really informative, view was published by the archaeologist, Alán Kralovánszky. ${ }^{5}$

After that, Gy. Siklósi made important advances in the topographical research of medieval Fehérvár - including the research of the town wall. He interpreted the first fortification of Fehérvár, on the highest point of the Inner Town (the hill of the bishop's basilica of today) as the early royal castle. The castle had existed - according to him - from the beginning of the $11^{\text {th }}$ century until 1249 , when the Latins ("Italian" hospeses) were settled, and it was torn down during the $13^{\text {th }}$ or the $14^{\text {th }}$ century. He assumed that at the time of King Béla IV, when the early royal castle was demolished, the building of the new defense system - that is the town wall - was begun, and this was completed by the end of the $13^{\text {th }}$ century. ${ }^{6}$ In his book, published in 2013 , he stated that "the name of 'terra castri Albensis' dating back to 1259 already designates the walled Inner Town". ${ }^{7}$ However, Gy. Siklósi did not have a direct archaeological (based on authentic excavation with stratigraphic data) or documentary evidence of the building date of the town wall.

Attila Zsoldos recently enumerated the historical arguments having for the stone wall been built on the border of the dry land, "thus, the area of Alba civitas mentioned in the early sources was essentially the same as the walled Inner Town of Fehérvár, the so-called Castle, in the Late Middle Ages". ${ }^{8}$ His main arguments are that according to the legends King St. Stephen founded the Virgin Mary Provostry Church "in Fehérvár" - not near to it -, and he finds it unlikely that the provostry church would have forgone the safety offered by the walls. He argued that the area to which King Béla I, his bishops, his noblemen and their retinue retreated in 1061 could be larger than the "early royal castle". He noted that there is not any mention of the damage of the building complex of the basilica during the pagan revolt, from which he concluded that "the provostry enjoyed the protection of the walls of Alba civitas far before the middle of the $13^{\text {th }}$ century". Moreover, in the castle there must have been room for the palace of the Veszprém's bishop, the royal salt depository and the prison. ${ }^{9}$ According to István Feld there is not any archaeological trace of such a wall - neither as an earth and timber rampart nor as a stone wall. ${ }^{10}$

\section{THE WESTERN TOWN WALL AND ITS EXCAVATED SECTION AT 20 JÓKAI STREET (TODAY: THE CISTERCIAN ORDER'S ST. STEPHEN HIGH SCHOOL)}

Some parts of the western wall of Fehérvár still stand now, built in to the wall of 4, 6, 8 Jókai Street. Gy. Siklósi provided important information on the town wall trace with the results of the excavation of 8 Szabadság (today: Városház) Square (in the documentation: 3 Szabadságharcos Street), 2, 18, and 20 Jókai Street.

He opened research trenches (Figs 1-3) in the yard of 20 Jókai Street (at that time: Attila József Secondary School, now Cistercian Order's St. Stephen High School), where he excavated the 220-cm-wide remnants of the town wall and its rectangular tower. ${ }^{11}$ Based on his archaeological observations the wall was demolished down to the beam foundation along an 8-meter-long stretch, and a tower was built on its place. He ascertained the date of the building of the tower at the end of the $13^{\text {th }}$ century based on $13^{\text {th }}$ century pottery found in its foundation. ${ }^{12}$ The town wall was built on a beam foundation at a depth of $280 \mathrm{~cm}$ measured from the ground level at the time of the excavation (Fig. 4). There is a narrow $(5-10 \mathrm{~cm}$ ) muddy black layer (layer 4 on the Fig. 4) - maybe trampled earth - between the beam foundation and the first building period of the town wall. The interpretation of this layer is not unambiguous because Gy. Siklósi did not cut through the wall in its full width.

According to the excavation log entry dated to November 9, 1981, the beam under the town wall was taken out of trench No. 8. On November, $10^{\text {th }}$ the beams (already here in plural) taken out of the town wall were cleaned and on November, $11^{\text {th }}$ they were transferred to the museum. ${ }^{13}$ They received accession numbers $(81.489 .1-7)$ and black-white photos were taken of them (Fig. 5/1-2). ${ }^{14}$

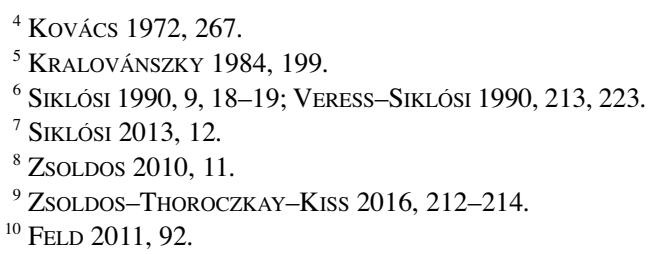

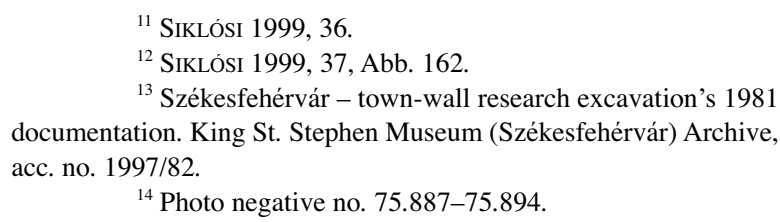

${ }^{13}$ Székesfehérvár - town-wall research excavation's 1981 documentation. King St. Stephen Museum (Székesfehérvár) Archive, acc. no. $1997 / 82$.

${ }^{14}$ Photo negative no. $75.887-75.894$. 

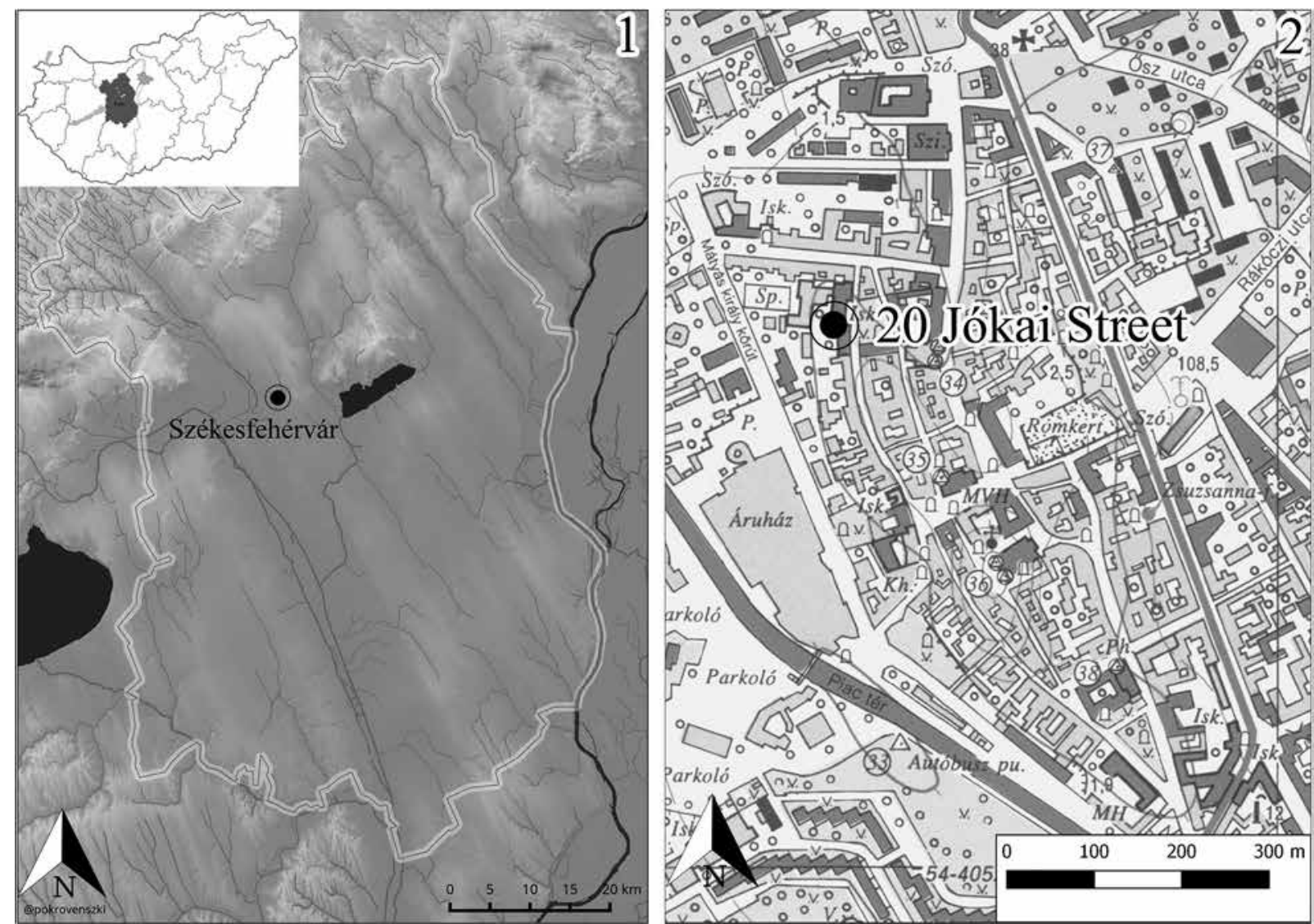

Fig. 1. 1: The location of Székesfehérvár in Fejér County (Hungary); 2: The archaeological site at 20 Jókai Street in Székesfehérvár

Gy. Siklósi invited Emil Horváth to take samples from and photos on two beams (acc. no.: 81.489 .1 and 81.489.6, dendrochronological id: Szfv7 and Szfv8) stored at the property (17 Megyeháza Street) of the Szent István Király Museum on 18 January 2009. The motivation was to perform a dendrochronological analysis in order to validate the presumed late $13^{\text {th }}$ century construction date of the stone wall with a potentially successful dating. We are not aware of the fate of the beams; however both the accession numbers and the original photographs in the museum's archive identified the beams beyond doubt (Fig. 5).

\section{DENDROCHRONOLOGICAL AND RADIOCARBON ANALYSIS OF THE BEAM FOUNDATION}

\section{Dendrochronological analysis}

Cross sections of Szfv7 and Szfv8 were processed by machine operated abrasive belts with gradually finer grit size until the tree-ring structure became clearly visible. Tree-ring sequences were carefully checked and rings were counted. ${ }^{15}$ For both disks, 4 radii were measured and the series were checked for the correctness of measurements within the disks. Finally, the mean of the tree-ring series was determined for both disks and used in the analysis. A LINTAB digital-positioning table and TSAP Win 4.68 software ${ }^{16}$ were used to measure the annual increments to a precision of $0.01 \mathrm{~mm}$, as well as for averaging the individual series and cross-dating the growth series by means of graphical comparison to each other.

The number of tree rings counted was 236 and 216 in Szfv7 and Szfv8, respectively (Fig. 8). The measurement series could be synchronized both within samples and between the two samples up to the $182^{\text {nd }}$ position of

${ }^{15}$ Stokes-SMiLey 1968.

${ }^{16}$ RINN 2005. 


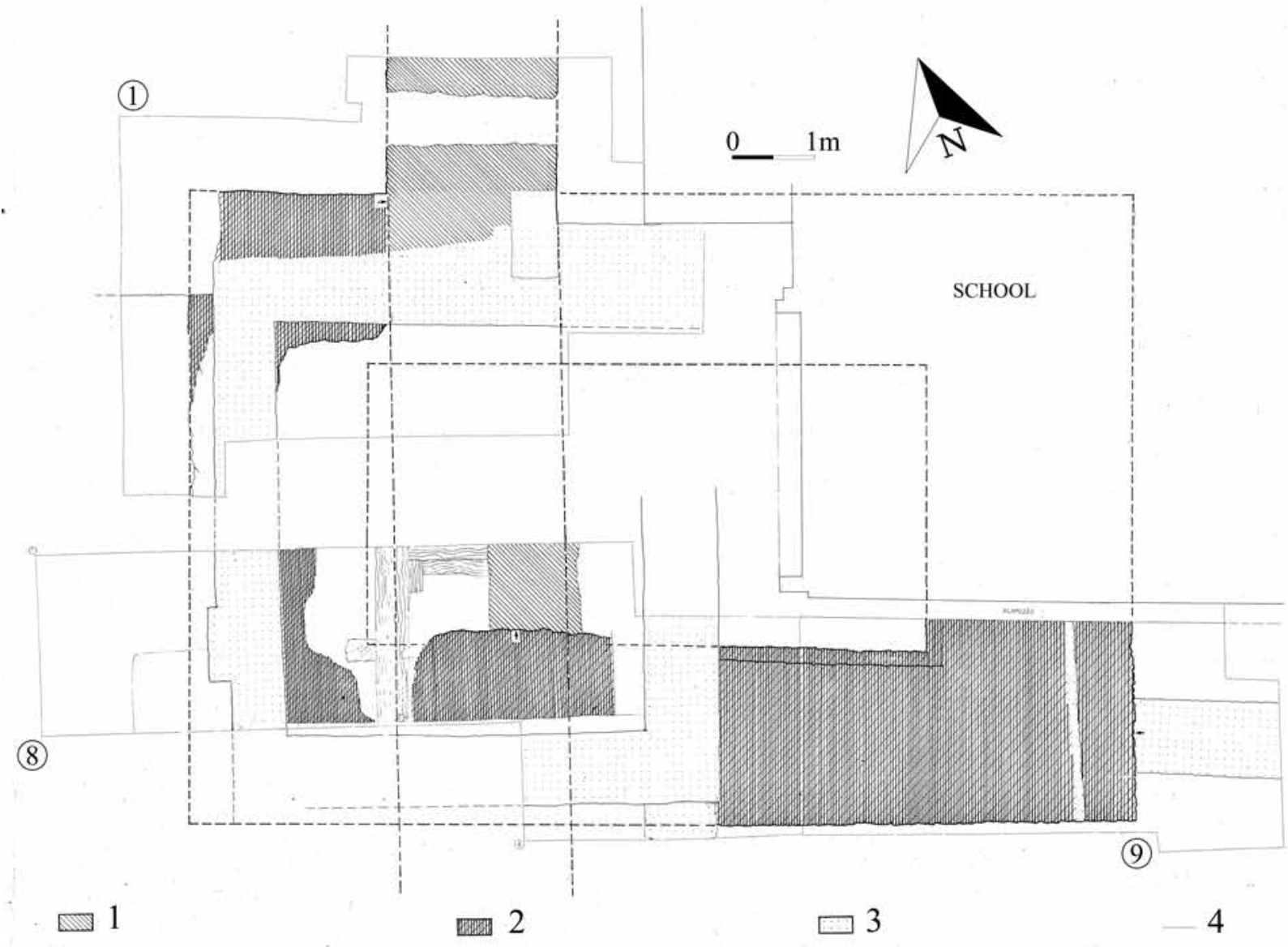

Fig. 2. The excavated stone town wall and the rectangular tower in the courtyard of 20 Jokai Street with trenches No. 1,8 , and 9. 1: The first building period of the ramparts; 2 : The second building period of the ramparts; 3 : Walls from the Baroque period; 4 : Boundary

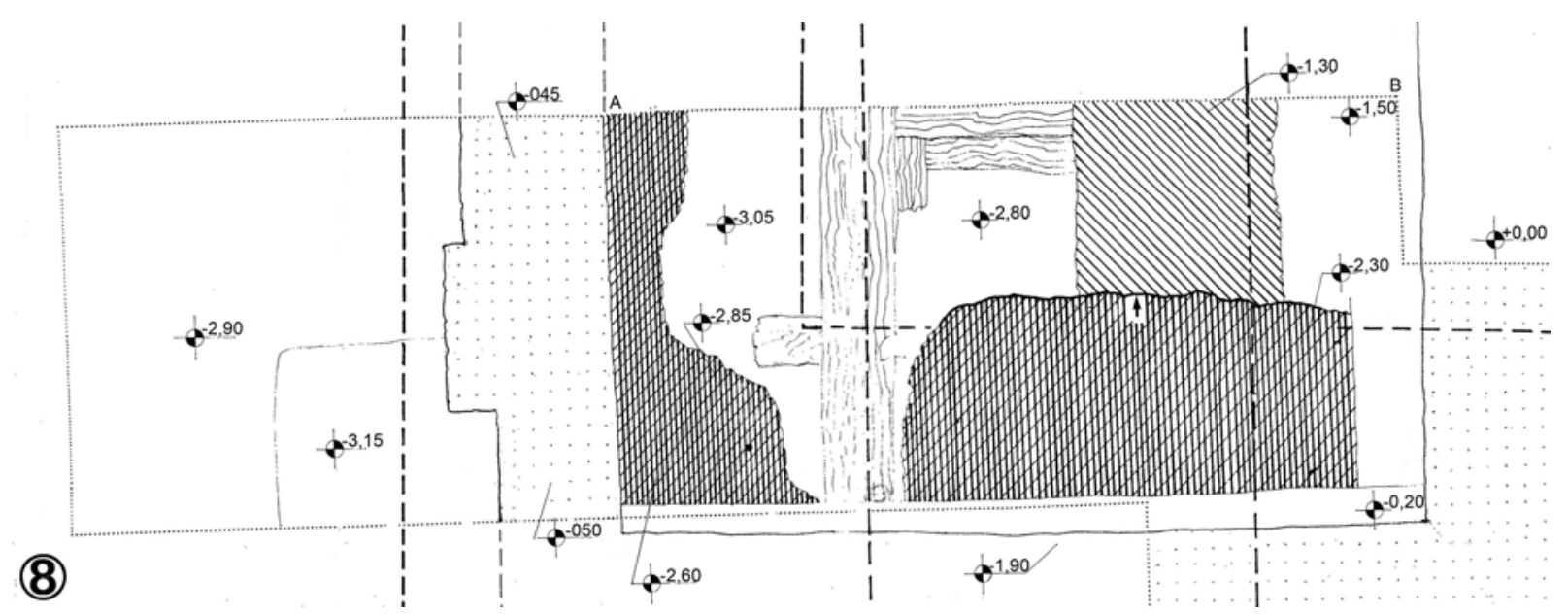

Fig. 3. Trench No. 8 in the courtyard of 20 Jókai Street 


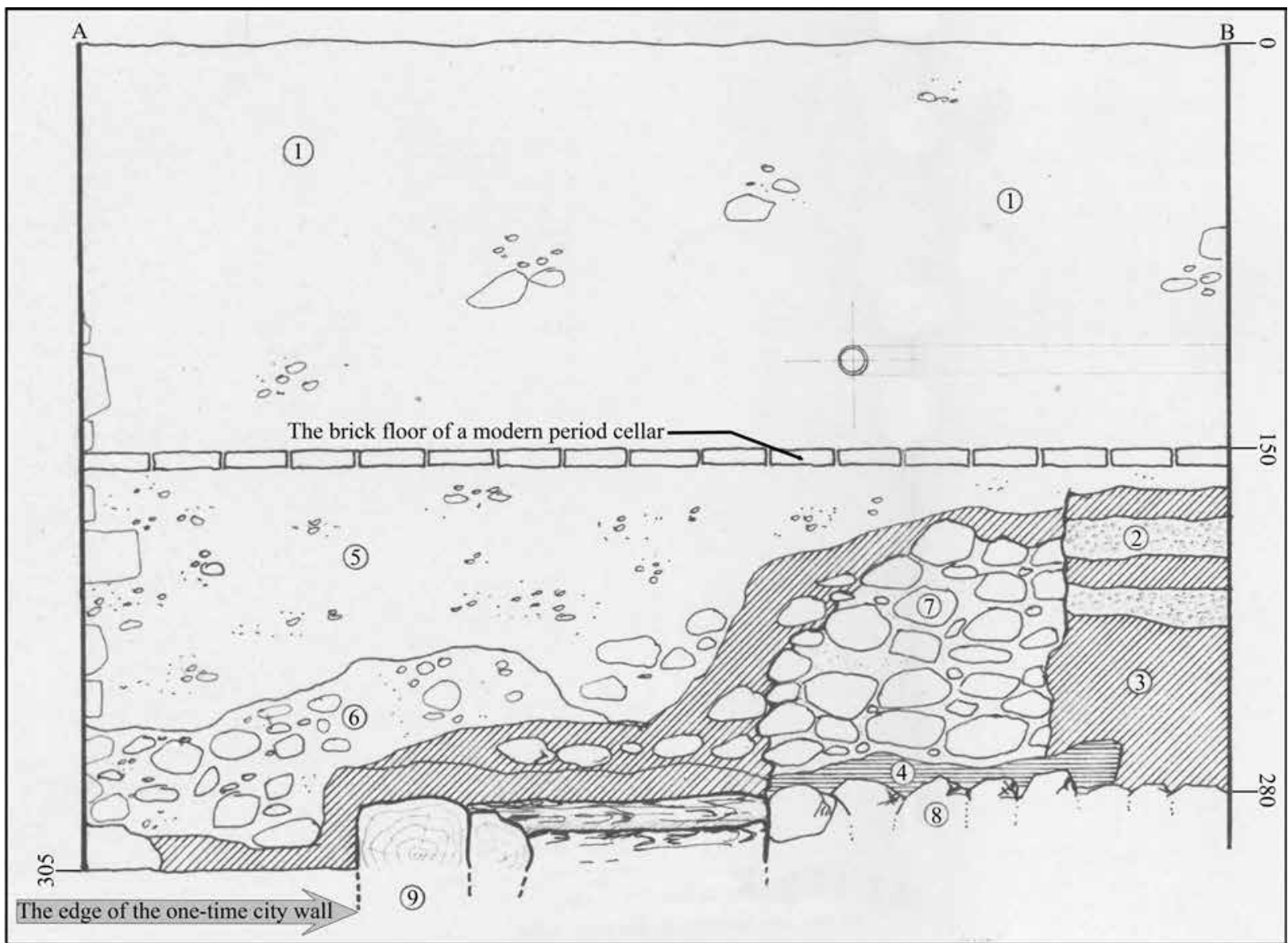

Fig. 4. The north section (A-B) of trench No. 8 in the courtyard of Jókai Street 20.

1: The most recent upfilling; 2 : The walking (ground) level made of construction debris; 3-4: Black muddy layer;

5: Modern leveling (floor of a cellar); 6: Debris from the demolished tower 7: "Town wall II" in the documentation of Gy. Siklósi (presumably the town wall as the first building period of the stone ramparts); 8: "Town wall I" in the documentation of Gy. Siklósi (maybe the tower, as the second building period of the stone ramparts); 9: The beam foundation of the town wall

their joint record (Fig. 8). However, the measurement uncertainty became proportionately larger and the risk of erroneously indentified tree-ring boundaries is also higher in the slow-growth older sections of both samples. This may be the reason why the individual measurement series along the different radii lost the excellent correspondence and the synchronicity between the mean curves also decreased considerably. Similar patterns of increment records are still recognizable but in slightly shifted positions over this latter section. However, given the lack of additional replicates it was impossible to correct the potential measurement errors reliably. Therefore, regarding the potential measurement errors of the cambially oldest sections of the samples, only the mean ringwidth chronology of a section of 181 rings built from the merged Szfv7 and Szfv8 records was compared to nearby oak master chronologies to provide an independent date supporting the potential archaeological interpretation and trace the potential distal/ proximal origin of the used timber. We have to note that a sufficiently long (i.e. extending back before the $13^{\text {th }}$ century) local oak reference chronology is not available. ${ }^{17}$ Therefore four sufficiently long quality checked oak master chronologies were involved from the surroundings such as East Austria (period covered: 931-2011) ${ }^{18}$ Moravia (period covered: 881-2014), ${ }^{19}$ Slovakia (period covered: 967-2013) ${ }^{20}$ and South Germany or Central Europe (period covered: 10-1950). ${ }^{21}$ However, clear and statistically robust agreement was found neither in the presumed

\footnotetext{
${ }^{17}$ Morgós 2007; Grynaeus 2015.

${ }^{18}$ GEIHOFER et al. 2005.

${ }^{19}$ РRокор et al. 2017.
}

${ }^{20}$ Prokop et al. 2016.
${ }^{21}$ Huber-GierTZ-SiebenList 1970, 37-42; HolLstein 1980. 
$13^{\text {th }}$ century nor outside that. Should however be noted that replication strongly declines before $\sim 1250$ AD in the geographically closer (East Austrian and Slovakian) reference chronologies.

\section{Radiocarbon measurement and calibration}

Small blocks containing 3 and 11 tree rings were sliced from Szfv8 (Tab. 1). 116 annual increments were counted between the central rings of the blocks and 82 rings were counted from the central ring of the outer block to the edge of the sample. Radiocarbon analysis was performed on the extracted $\alpha$-cellulose. Sample preparation and radiocarbon analysis were performed in the ${ }^{14} \mathrm{C}$ lab of the Hertelendi Laboratory of Environmental Studies, Institute for Nuclear Research, Hungarian Academy of Sciences, Debrecen. ${ }^{22}$

Measured targets were prepared using a sealed-tube graphitization method. ${ }^{23}$ The isotope ratios of ${ }^{14} \mathrm{C} /{ }^{12} \mathrm{C}$ and ${ }^{13} \mathrm{C} /{ }^{12} \mathrm{C}$ were measured using accelerator mass spectrometry (AMS), with the application of an EnvironMICADAS ${ }^{14} \mathrm{C}$ facility. ${ }^{24}$

The radiocarbon ages were calculated ${ }^{25}$ using the Libby half-life (5568 years) and were corrected for isotope fractionation using the AMS measured ${ }^{13} \mathrm{C} /{ }^{12} \mathrm{C}$ ratio, which accounts for both natural and machine fractionation.

The so-called wiggle-matching technique ${ }^{26}$ was employed in the calibration of radiocarbon results obtained from dendrochronologically cross-dated tree-ring sequences using the D_Sequence function of the OxCal v.4.27 program in conjunction with the Northern Hemisphere IntCal $13^{28}$ dataset. This means that, thanks to the precise $a$ priori knowledge provided by dendrochronological synchronization, i.e. the exact number of tree-rings between the blocks subjected to radiocarbon measurements, the radiocarbon calibration errors are minimized, and this allows for dating with considerably higher accuracy than in the case of single radiocarbon measurements. ${ }^{29}$

Table 1. The results of the radiocarbon analysis and modelled calendar date of the terminal ring of the Szfv8 historical oak sample. The unmodelled age range shows the simple calibration, while the modelled one represents the estimated age obtained by wiggle-matching calibration. Calibrated ages are reported with $95.4 \%(2 \sigma)$ probability. A: individual agreement percent of the OxCal wiggle-match model.

\begin{tabular}{|c|c|c|c|c|c|c|}
\hline \multirow[t]{2}{*}{ Sample code } & \multirow[t]{2}{*}{$\mathrm{n}^{\mathrm{a}}$} & \multirow[t]{2}{*}{ lab code ${ }^{b}$} & \multirow[t]{2}{*}{$\begin{array}{l}{ }^{14} \mathrm{C} \text { age } \\
\mathrm{BP}\end{array}$} & $\begin{array}{l}\text { unmodelled } \\
\text { cal AD }(95.4 \%)\end{array}$ & $\begin{array}{l}\text { modelled } \\
\text { cal AD }(95.4 \%)\end{array}$ & $\mathrm{A}(\%)$ \\
\hline & & & & from-to & from-to & \\
\hline Szfv8/1 & 3 & DeA-4834 & $1198 \pm 18$ & $772-884$ & $\begin{array}{l}780-812(31.4 \%) \\
824-879(64.0 \%)\end{array}$ & 105.4 \\
\hline Szfv8/2 & 11 & DeA-4835 & $1086 \pm 17$ & $\begin{array}{l}896-928(30.6 \%) \\
940-998(63.0 \%) \\
1005-1012(1.8 \%)\end{array}$ & $\begin{array}{l}896-928(31.4 \%) \\
940-995(64.0 \%)\end{array}$ & 104.2 \\
\hline last extant ring & & & & & $\begin{array}{l}978-1010(31.4 \%) \\
1022-1077(64.0 \%)\end{array}$ & \\
\hline
\end{tabular}

a: number of tree-rings counted in the block of sample used for radiocarbon analysis

${ }^{\mathrm{b}}$ : individual laboratory code of the Debrecen radiocarbon lab $^{30}$

The wiggle-matching procedure constrained the single-sample calibrated ranges of the two ${ }^{14} \mathrm{C}$ results available from the Szfv8 to a considerable extent $(T a b .1)$. The overall series OxCal agreement index $\left(\mathrm{A}_{\text {comb }}\right)$ was $106.9 \%$ and this proved to be satisfactory. The $95 \%$ probability range of the Bayesian wiggle-match calibration was split over two adjacent periods (Table 1). The obtained calibrated age ranges of the last extant ring of Szfv8 are 978-1010 cal AD or 1022-1077 cal AD. No trace of bark was observed on the beams; however the outermost 13 and 19 rings could be identified as sapwood in the course of the microscopic investigation of Szfv7 and Szfv8, re-

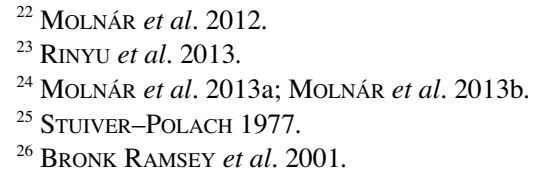

${ }^{23}$ RiNYu et al. 2013.

${ }^{4}$ Molnár et al. 2013a; Molnár et al. 2013b.

${ }^{26}$ BRONK RAMSEY et al. 2001.

\footnotetext{
${ }^{27}$ BRONK RAMSEY 2009.

${ }^{28}$ REIMER et al. 2013.

${ }^{29}$ Pearson 1986.

${ }^{30}$ MoLnÁr et al. 2012.
} 


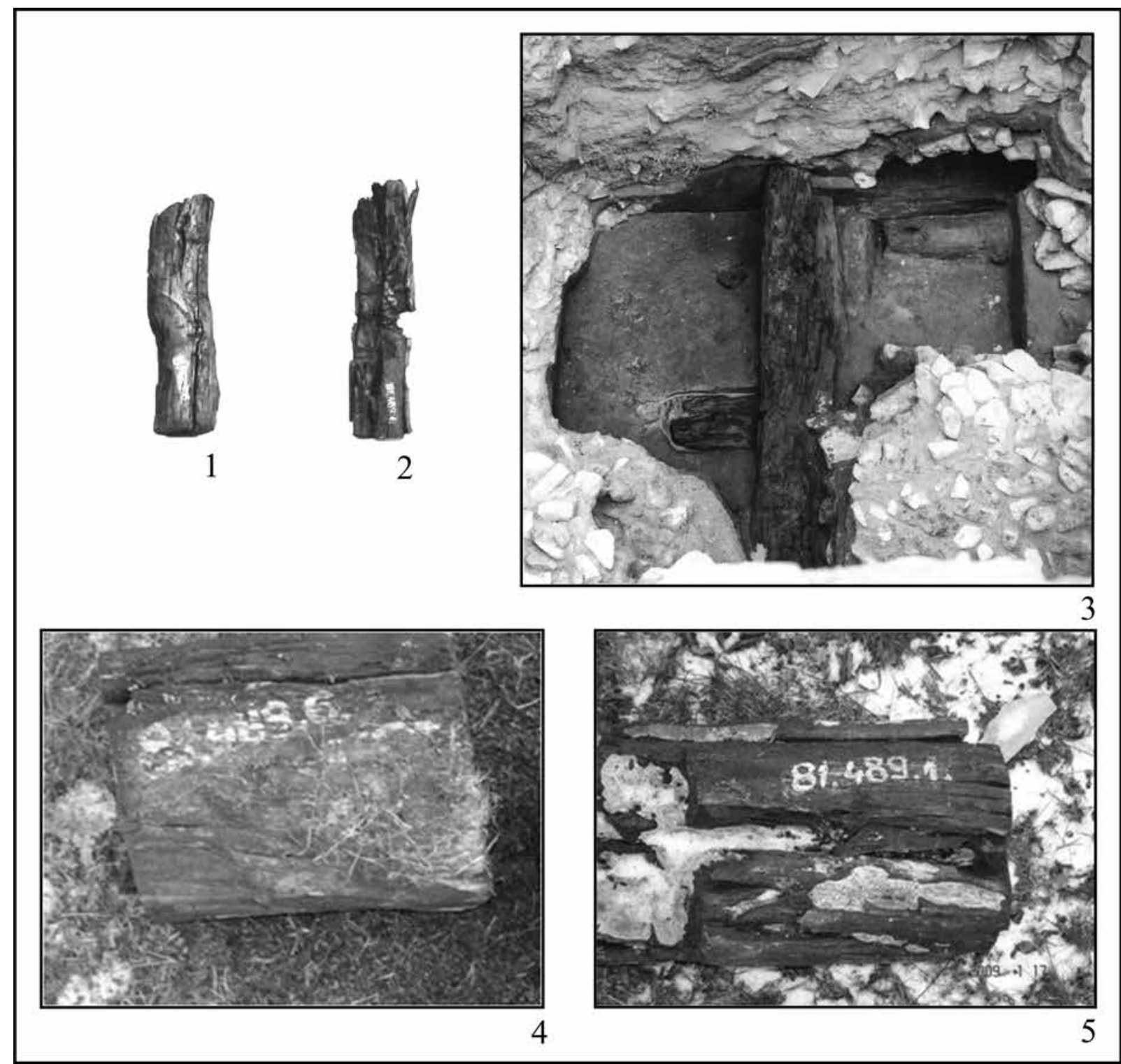

Fig. 5. 1-2: The photos of the beams acc. no. 81.489 .6 and 81.489.1 (Szfv8 and Szfv7) from the King St. Stephen Museum (Székesfehérvár) Archive; 3: The photo of the beam foundation of the town wall in the courtyard of 20 Jókai Street in the trench No. 8;

4-5: The photos of the wooden beams acc. no. 81.489.6. and 81.489.1. (Szfv8 and Szfv7)

in the courtyard of the 17 Megyeház Street building of the St. Stephen Museum

spectively. The number of counted sapwood rings fits in the range of the average number of rings in sapwood of oaks in Hungary $(17+2 /-5),{ }^{31}$ and is also close to the value found in a regional study in the Bakony Mts (19.8). ${ }^{32}$ Therefore, the sapwood may be considered to be complete and the age of the outermost tree ring taken as indicating the earliest possible felling date of the tree, thus assigning a terminus post quem to the construction of the beam foundation and the erection of the stone wall. 

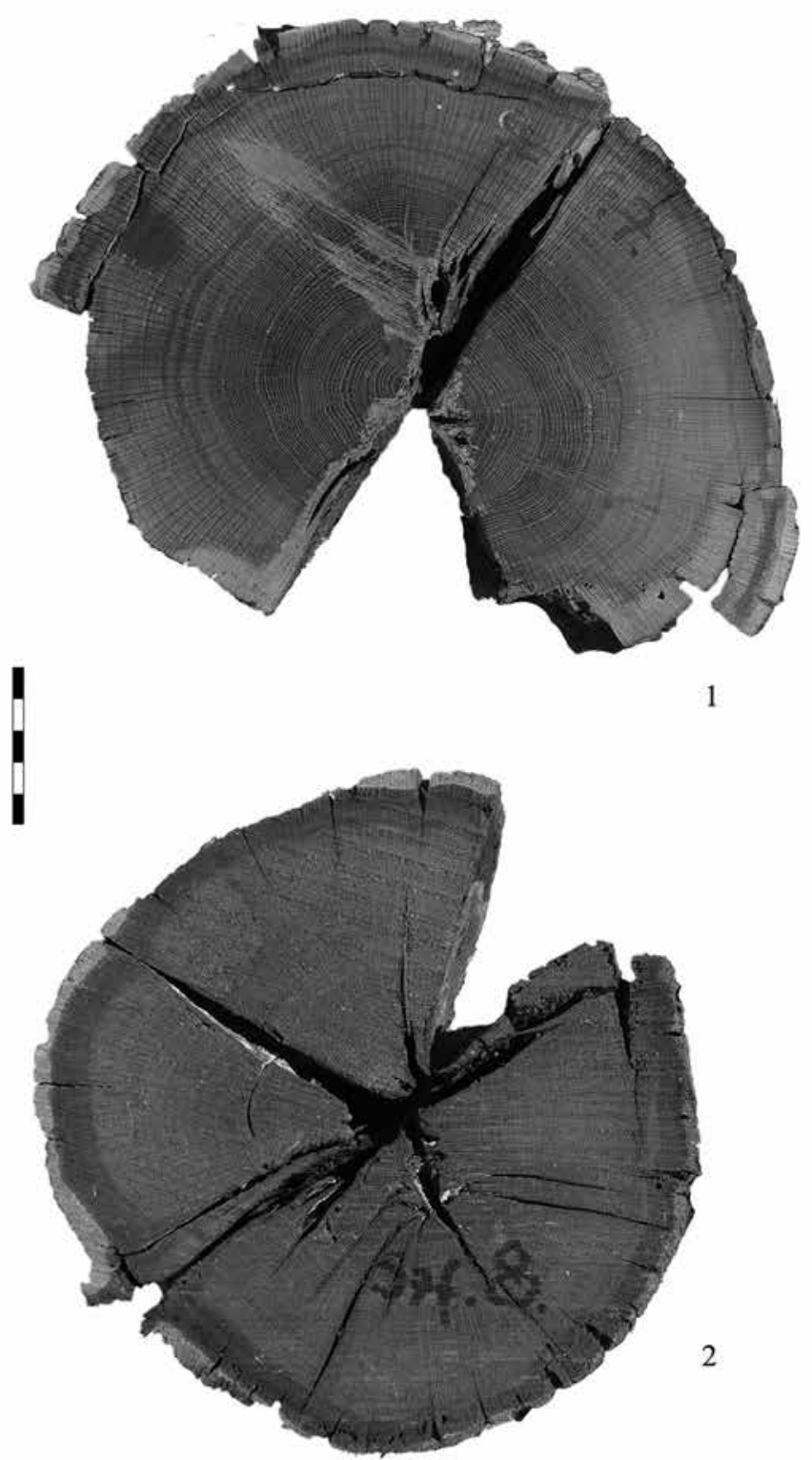

1

Fig. 6. Macroscopic view of the horizontal cross sections of Szfv7 (reg. num: 81.489.1.) and Szfv8 (reg.num: 81.489.6.) beams

\section{HISTORICAL EVALUATION}

Town walls and castles built of stone and mortar began to be built in the territory of the Kingdom of Hungary - apart from some exceptions - after the Mongol invasion (A.D. 1241-42). ${ }^{33}$ However, the building of town walls only became widespread in the $14^{\text {th }}$ century. Nevertheless, most of the 110 fortified settlements of the Kingdom of Hungary were not surrounded by stone walls, but with palisades and trenches or only a castle was built. ${ }^{34}$

Fehérvár is one of the exceptions, as most researchers have dated the stone castle (early royal castle? or count's [in Hungarian: ispán] fortress? $)^{35}$ that once stood on the hill of the bishop's cathedral to the early $11^{\text {th }}$ century

${ }^{33}$ SÁNDORFI 1979, 248.

${ }^{34}$ GulYás 2014, 131.

${ }^{35} \mathrm{~Gy}$. Siklósi interpreted the wall remains observed by Árpád Dormuth and himself as parts of the early royal castle (SiKLÓsI Acta Archaeologica Academiae Scientiarum Hungaricae 69, 2018
1999, 10-13; SIKLÓSI 2013, 12). Recently, I. Feld doubted the interpretation of the wall remains as the early royal castle (FELD 2011, 91), A. Zsoldos still considered them to be the count's castle (ZsolDos 2010, 10). 

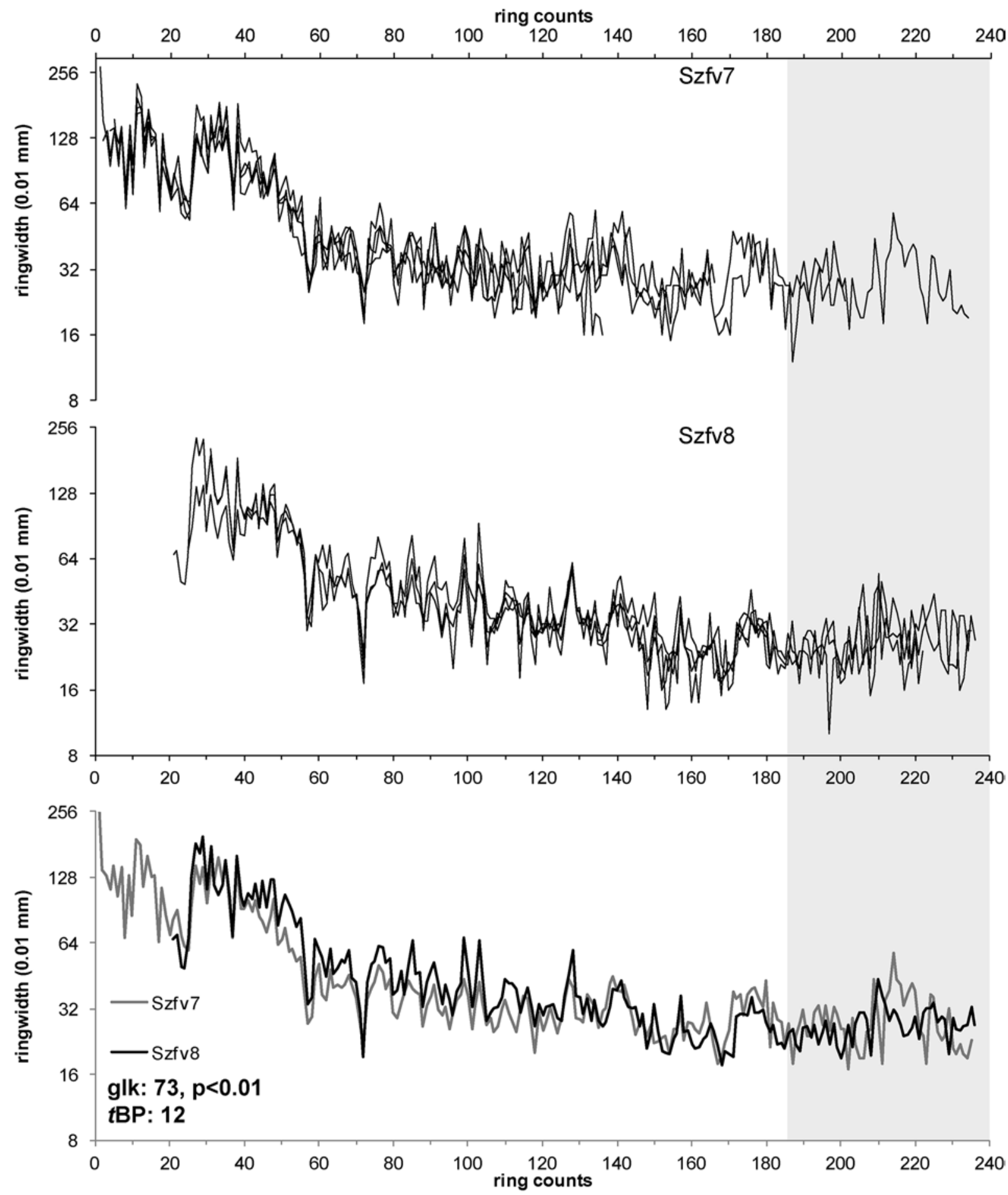

Fig. 7. Graphical illustration of the ringwidth measurements. Ringwidth series measured along individual radii on Szfv 7 and Szfv8 are shown in the top and middle panels, respectively. The mean curves are shown in the bottom panel. Standard dendrochronological statistics, such as percentage of agreement (GLK\%) (ECKSTEIN-BAUCH 1969) and modified t value (tBP) (BAILLE-PILCHER 1973) corresponding to the presented synchronized position are displayed in the bottom panel 


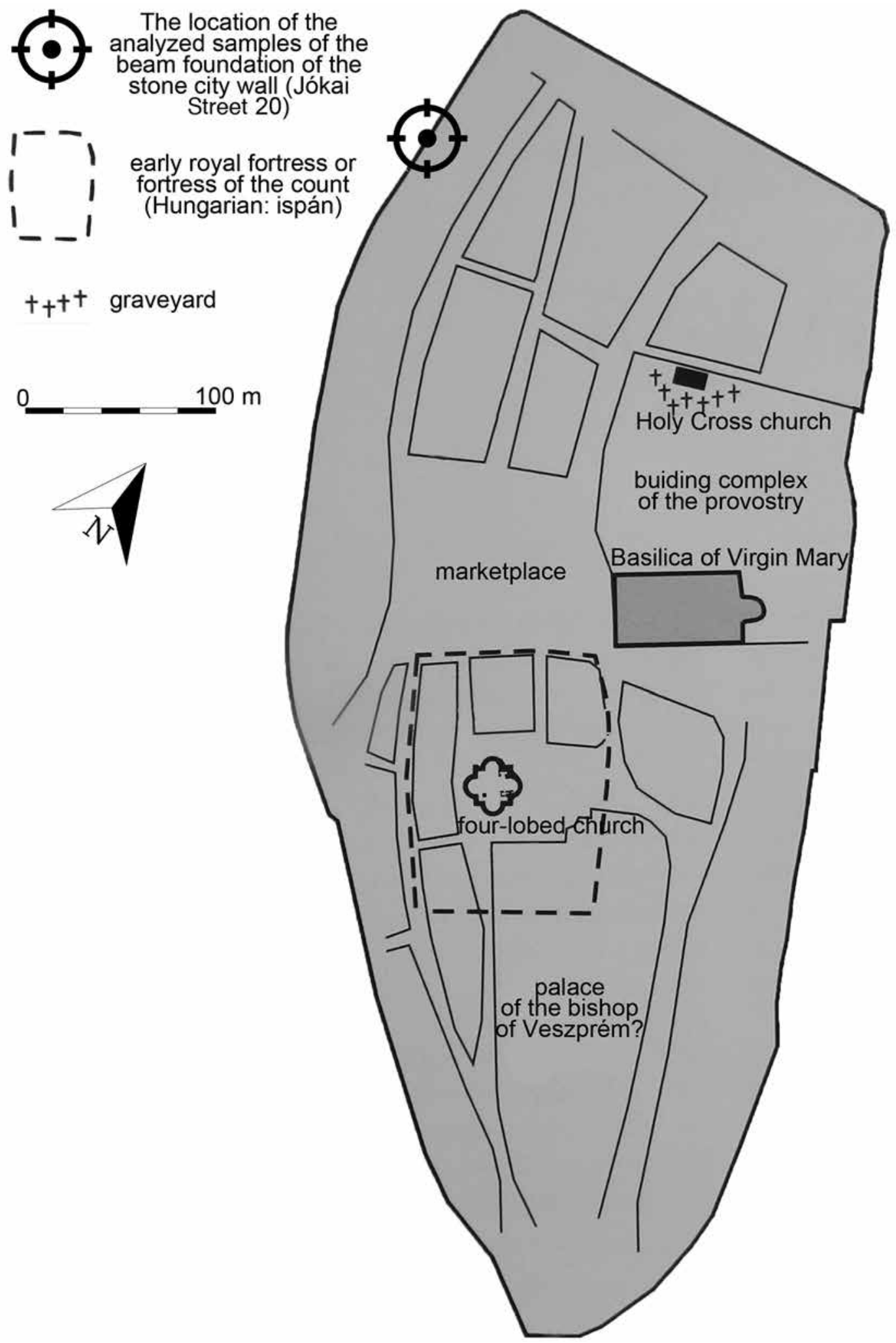

Fig. 8. The Inner Town of Székesfehérvár in the $11^{\text {th }}$ century (based on Zsoldos 2016, Fig. 191 and SiKLósi 1999, Fig. 40, Fig. 65) 
(Fig. 8) ${ }^{36}$ Recently, it has emerged as one historian's hypothesis that not only the stone castle, but the town wall itself was built on the borders of the dry land in the $11^{\text {th }}$ century ${ }^{37}$ If we accept the foundation date of the Virgin Mary Provostry Church as about 1018, ${ }^{38}$ and the arguments that King St. Stephen founded the provostry ,in Fehérvár", also within the castle and not near to it, and the ecclesiastical building with highest priority would not have lacked the safety offered by the walls, ${ }^{39}$ then we could date the construction of the stone wall encircling the borders of the dry land - also the town centre known from the Late Middle Ages - to earliest, the late 1010s. By this time, King St. Stephen had made Fehérvár his royal seat ${ }^{40}$ As the latest date of the beginning of the town wall building - according to the above historical hypothesis - we could designate as 1038, the year of King St. Stephen's death and the consecration of the Virgin Mary Provostry Church. ${ }^{41}$ Thus, we can accept as trustworthy the description of the Illuminated Chronicle (in Hungarian: Képes Krónika) in about 1358 referring to the town wall, that in 1046 King Peter “... crossed the Danube to march on Fehérvár. However, the Hungarians got wind of his intention, forestalled him, occupied the belltowers and the bastion towers of the town, closed the gates and excluded him". ${ }^{42}$ Even though the towers could not exist ${ }^{43}$ - they were built at the turn of the $13^{\text {th }}-14^{\text {th }}$ centuries ${ }^{44}-$ the town walls could get in his road. We have to note that the result of the radiocarbon dating allows a later period until 1077 for the beginning of the town wall building.

Wiggle-matched calibrated ages placed the felling date of the trees found in the beam foundation of the western town wall to the late $10^{\text {th }}$-early $11^{\text {th }}$ centuries or to the second and third quarters of the $11^{\text {th }}$ century. The probability of the second and third quarters of the $11^{\text {th }}$ century is higher compared to the earlier period (Table 1), in addition the late $10^{\text {th }}$ century predates the foundation of Fehérvár, further arguing in favour of an $11^{\text {th }}$ century felling date of the trees used for the beam foundation. Interestingly, the numerical ages cannot support the originally presumed late- $13^{\text {th }}$ century construction of the stone wall, and instead include the first decades of the $11^{\text {th }}$ century, overlapping with the age of King Saint Stephen and allowing a correspondence with the assumed date of a town wall being built in approx. 1018-1038. Although, theoretically, recycled timber at a construction time in the late-13 ${ }^{\text {th }}$ century should not be excluded, however recycling of 180-240 years old timber with hardly eroded sapwood (as noted above the sapwood can be considered to be complete) seems very unlikely.

Assuming that the inferred date of the beam foundation observed properly indicates the date of the erection of the medieval stone wall, this highlights the prominent importance of Fehérvár in the age of King Saint Stephen, since this may well be the first settlement in the Ancient Hungarian Kingdom which was encircled by a stone wall. ${ }^{45}$

After the fall of the Western Roman Empire the first stone town walls appeared replacing the former fortifications (tower houses, castles) in Italy and north of the Alps around 1000 (e.g. in Genoa, in Würzburg). However, most of the stone town walls were built all over in Europe in the $12^{\text {th }}-13^{\text {th }}$ centuries. ${ }^{46}$ While in Anatolia the entire area of many Byzantine towns were encircled with representative stone walls at the beginning of the $5^{\text {th }}$ century, much smaller area of the towns were encircled with a wider and stronger stone wall in the $7^{\text {th }}-8^{\text {th }}$ centuries to defend against the Arab attacks. ${ }^{47}$ This type of stone wall construction - which was out to reduce the extent of the late antique girdle of walls of the city - is known even in the $9^{\text {th }}$ century in Anatolia, ${ }^{48}$ but it occurred in West-Europe, too (e.g. in the city of Worms). ${ }^{49}$ There were also several stone town walls in the European territories of the Byzantine

${ }^{36}$ FITZ-CsÁSZÁR-PAPP 1966, 12; FÜGEDI 1967, 33-34; SIKLÓSI 1990, 9; SIKLÓSI 1999, 14; SIKLÓSI 2013, 12; ZsOLDOS 2010, 10.

${ }^{37}$ ZsOLdOs 2010, 11; ZsOLDOS-THOROCZKAY-KISs 2016, $212-214$.

${ }^{38}$ ZsOLDOS-THOROCZKAY-KISS 2016, 67-72.

${ }^{39}$ Zsoldos-ThOROCZKAY-KISs 2016, 212-214. Gy. Siklósi also thought that there had to be some kind of ramparts around the provostry church, however, he assumed a „Domburg” around the royal provostry, near the early royal castle (SIKLósi 1999, 10).

${ }^{40}$ GYÖRFFY 2000, 316-321.

${ }^{41}$ VERESS-SIKLÓSI 1990, 14; ZsOLDOS-THOROCZKAY-KISS 2016,72 .

${ }^{42}$ Képes Krónika 1964, 53.

${ }^{43}$ VERESS-SiKLÓsI 1990, 17.

${ }^{44}$ SIKLÓSI 1999, 59

${ }^{45}$ The dating of the first construction period of stone castle and town walls is problematic not only in the case of Fehérvár. The building of the town wall of Pest was dated on the era of King Matthias (1458-1490), but there was another early town wall, that could be built in the first half of the $13^{\text {th }}$ century, even before the Mongol Invasion (CsORBA 1976, 349, 354; IRÁSNÉ MELIS 1976, 329). According to some researchers there was already a stone castle in Esztergom-Várhegy in the $10^{\text {th }}$ century, at the time of Grand Prince Géza (GYÖRFFY 2000, 195; ZoLNAY 1983, 64; HoRVÁTH 2015, 193-256), but only from the $12^{\text {th }}$ century is there clear data about its existence (FELD 1990, 11; RABB 2004, 20). The first data about the stone town wall of the Royal Town of Esztergom came from the end of the $13^{\text {th }}$ century (RABB 2005 , 50 ), and about the stone wall of Esztergom Víziváros only from the $14^{\text {th }}$ century (RABB 2005, 23, 80, 84).

${ }^{46}$ Gerỏ 1975, 25; PeYer 1995, 10.

${ }^{47}$ NIEWÖHNER 2010, 251, 258.

${ }^{48}$ NIEWÖHNER 2007, 125-126.

${ }^{49}$ ARMKNECHT 1971, 54-65. 
Empire in the $10^{\text {th }}-11^{\text {th }}$ century, e.g. in Thessaloniki and in Constantinople the late antique city walls formed the basis of the medieval defence system..$^{50}$ In the eastern half of the former Roman Empire - in contrast with Western Europe - stone town walls were also built in the Early Middle Ages. In the light of the early medieval town wall construction of the Byzantine Empire, the town wall of Fehérvár cannot be regarded as "early", but in relation to the areas east of the Rhine, it was one of the earliest stone town walls built after the fall of the Western Roman Empire.

The building of the early town wall of Fehérvár was probably ordered by the king, on account of its high cost and the fact that the building of town walls was the privilege of the king in the $10^{\text {th }}-12^{\text {th }}$ centuries all over in Europe. ${ }^{51}$ Besides the defensive aspect, the prestige of the imposing stone wall could also have motivated the building, as Fehérvár became a royal seat under the rule of St. Stephen. According to A. Zsoldos there was probably a lot of free area inside the town wall, as military reasons accounted for the erection of the wall on the frontiers of the dry land. ${ }^{52}$

\title{
SUMMARY
}

Dendrochronological analysis of two oak beams found in the foundation of a mediaeval section of the western town wall of Fehérvár revealed well-matched growth patterns for the timbers. Calibration of ${ }^{14} \mathrm{C}$ results of two subsamples from Szfv8 applying the wiggle-matching technique argued against the presumed mid- $13^{\text {th }}$ century construction date of this section of the stone wall because the last extant ring of the samples pointed to a date not later than the $11^{\text {th }}$ century. Theoretically, recycled timber should not be excluded however recycling of 180-240 year old timber with hardly eroded sapwood seems very unlikely.

Accepting the primary use of the wooden beams, historical arguments suggest that the second half of the 1010s could be the earliest date for building the stone town wall erected on the frontiers of the dry land. However, the construction of the stone wall was probably begun during King St. Stephen' reign; so at latest by 1038. Thus, the medieval town of Fehérvár is classifiable among the earliest towns east of the Rhine which is encircled by a stone town wall following the fall of the Western Roman Empire. In the territory of the medieval Hungarian Kingdom, it was also the first town to be protected by a stone wall. Besides the defensive aspect, the prestige of the imposing stone wall could also have motivated the building, as Fehérvár became a royal seat under the rule of St. Stephen.

The ruins of the ancient town wall have been successfully documented in many archaeological excavations over the past 5-6 years; ${ }^{53}$ nevertheless, given the lack of age determination, assigning construction periods remained rather speculative. Breakthroughs and a satisfying solution to the questions of the location and chronology of the construction periods of the town walls of Fehérvár can be expected from further archaeological excavations and scientific age determination of additional samples in the near future.

\section{ACKNOWLEDGEMENTS}

Thanks for the support of the "Lendület" program of the Hungarian Academy of Sciences (LP2012-27). This is contribution No.56 of 2ka Palæoclimatology Research Group.

We are grateful to Dr. Piroska Biczó for her useful comments on the archaeological and historical chapters of this publication.

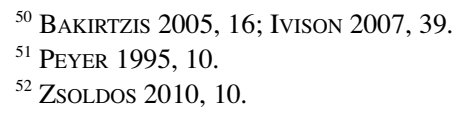

\author{
${ }^{53}$ For the construction of the north town wall, see: SzÜCSI \\ 2015; for the west wall, see SZÜCSI 2016, 187.
}


REFERENCES

ARMKNECHT 1971

BAILLE-PILCHER 1973

BAKIRTZIS 2005

BRONK RAMSAY 2009

BRONK RAMSAY et al. 2001

CsORBA 1976

ECKSTEIN-BAUCH 1969

FELD 1990

FELD 2011

FITZ-CsÁSZÁR-PAPP 1966 FÜGEDI 1967

GEIHOFER et al. 2005

GERŐ 1975

GRYNAEUS 1996

GRYNAEUS 2002

GRYNAEUS 2015

GULYÁs 2014

GYÖRFFY 1987

GYÖRFFY 2000

HOLLSTEIN 1980

HORVÁTH 2015

HuBER-GIERTZ-SIEBENLIST 1970

IRÁSNÉ MELIS 1976

IVISON 2007

Képes Krónika 1964
= K. H. ARmKnecht: Die Wormser Stadtmauer. Der Wormsgau. Zeitschrift der Kulturinstitute der Stadt Worms und des Altertumsvereins Worms 9 (1970/71) 54-65.

= M. G. L. BAILLE-J. R. PILCHER: A simple cross-dating programme for tree-ring research. Tree-Ring Bulletin 33 (1973) 7-14.

= N. BAKIRTZIS: The visual language of fortification façades: The walls of Thessaloniki. Mnemeio \& Perivallon 9 (2005) 15-34

= C. BRONK RAMSAY: Bayesian analysis of radiocarbon dates. Radiocarbon 51/1 (2009) 337-360.

= C. BRONK RAMSAY-J. VAN DER PLICHT-B. WENINGER: "Wiggle-matching" radiocarbon dates. Radiocarbon 43/2A (2001) 381-389.

= Cs. CsORBA: Pest városfalának vázlatos története (The outline of the history of the Pest town wall). BudRég 24 (1976) 349-368.

= D. ECKSTEIN-J. BAUCH: Beitrag zur Rationalisierung eines dendrochronologischen Verfahrens und zur Analyse seiner Aussagesicherheit. Forstwissenschaftliches Centralblatt 88/4 (1969) 230-250.

= I. FELD: A 13. századi várak az eddigi kutatásokban (Die ungarischen Burgen des 13. Jahrhunderts in den bisherigen Forschungen). In: Castrum Bene 1989. Ed.: L. Horváth. Gyöngyös 1990, 8-21.

= I. FELD: Székesfehérvár. Vár- és városfalak [Székesfehérvár. The castle and the town walls]. In: Fejér megye várai az őskortól a kuruc korig. Eds: Gy. Terei, Gy. Nováki, Zs. Mráv, I. Feld, S. Sárközy. Budapest 2011, 90-93.

= J. FITZ-L. CSÁsZÁR-I. PAPP: Székesfehérvár. Budapest 1966.

= E. FÜGEDI: Székesfehérvár középkori alaprajza és a polgárság kezdetei Magyarországon [The medieval layout of Székesfehérvár and the origins of the burgher class]. TeltudK 20 (1967) 31-45.

= D. Geihofer-M. Grabner-J. Gelhart-R. Wimmer-H. Fuchsberger: New master chronologies from historical and archaeological timber in Eastern Austria. In: EuroDendro 2005. Proceedings of the EuroDendro 2005, September 29th-October 1st 2005 Viterbo Italy. Eds: M. Sarlatto, A. di Fillipo, G. Piovesan, M. Romagnoli. Viterbo 2005, 50-51.

= L. GERŐ: A magyar várépítés kialakulása a honfoglalás korától - Jellegzetes építési korszakok és ezek történeti előzményei az európai várfejlődés keretében (Die charakteristischen Epochen des Burgbaues in Ungarn in Bezug auf die europäische Burgbauentwicklung). In: Várépítészetünk. Ed. L. Gerő. Budapest 1975, 9-44.

= A. GRYNAEUS: Progress of dendrochronological research in Hungary. Dendrochronologia 14 (1996) 223-226.

= A. GRYNAEUS: Dendrokronológiai kutatások és eredményei Magyarországon (The results of dendrochronological research in Hungary). FtK 132 (2002) 265-272.

= A. GRYNAEUS: Miről mesélnek a régi fák évgyürüi? Régészet, dendrokronológia, klímatörténet [What do the old tree-rings tell us? Archaeology, Dendrochronology and Climate History]. Budapest 2015.

= L. Sz. GuLYÁs: Városfalépítés a középkori Eperjesen [The building of the town wall in Eperjes in the Middle Ages]. In: Falak és választóvonalak a történelemben. A Nyíregyházi Főiskola Történettudományi és Filozófiai Intézete által 2012. november 29-30-án rendezett társadalomtudományi konferencia előadásai. Eds: A. Buhály, G. Reszler, Gy. Szoboszlai. Nyíregyháza 2014, 127-142.

= GY. GYÖRFFY: Az Árpád-kori Magyarország történeti földrajza. II.: D-Gy [Historical Geography of Hungary during the Árpád Dynasty]. II.: D-Gy. Budapest 1987.

= GY. GYÖRFFY: István király és müve [King Stephen and His Work]. Budapest 2000.

= E. Hollstein: Mitteleuropäische Eichenchronologie. Trierer dendrochronologische Forschungen zur Archäologie und Kunstgeschichte. Mainz 1980.

= I. HoRvÁth: Az esztergomi Várhegy régészeti kutatása, 1966-1999 (Archaeological researches on Esztergom's Castle Hill, 1966-1999). In: In medio regni Hungariae. Régészeti, művészettörténeti és történeti kutatások „az ország közepén” (Archaeological, Art Historical, and Historical Researches 'in the Middle of the Kingdom'). Eds: E. Benkö, K. Orosz. Budapest 2015, 193-256.

= B. HUBER-V. GIERTZ-SIEBENLIST: Unsere tausendjährige Eichen-Jahrringchronologie durchschnittlich 57 (10-150)-fach belegt. ÖAW Math.-naturwiss. Klasse 178 (1970) 37-42.

$=\mathrm{K}$. IRÁSNÉ Melis: Beszámoló a középkori Pest város területén végzett régészeti kutatások eredményeiröl (Report on the results of the archaeological research conducted in the area of the medieval town of Pest). BudRég 24 (1976) 313-348.

= E. A. Ivison: Armorium in the Byzantine Dark Ages (seventh to ninth centuries). In: Post-Roman Towns, Trade and Settlement in Europe and Byzantium. 2.: Byzantium, Pliska and the Balkans. Ed.: J. Henning. Berlin-New York 2007, 25-60.

= D. Dercsényi - K. CsapodinÉ GÁRdonyi: Képes Krónika [Chronicon Pictum]. Trans. by L. Geréb. Ed.: L. Mezey. Budapest 1964. 
KERN 2007

KovÁcs 1972

KRALOVÁNSZKY 1984

MOLNÁR et al. 2012

MolnÁR et al. 2013a

MolNÁR et al. 2013b

MoRGÓs 2007

NAGY 1972

NIEWÖHNER 2007

NIEWÖHNER 2010

PEARson 1986

PEYER 1995

PROKOP et al. 2016

PROKOP et al. 2017

RABB 2004

RABB 2005

REIMER et al. 2013

RINN 2005

RINYU et al. 2013

SÁNDORFI 1979

SIKLÓSI 1990
= Z. KERN: Évgyürüvizsgálatok a Balaton-felvidéken és a Déli-Bakonyban (Tree-ring research in South Bakony Mts and Balaton Highland). In: Az erdő és a fa régészete és néprajza - Kézművesipartörténeti megközelítésben (Archaeology and Ethnography of Forest and Wood - In approximation of handicraft history). Ed.: J. Gömöri. Sopron 2007, 89-102.

= P. KovÁcs: Megjegyzések Székesfehérvár középkori topográfiájának kutatásához [Remarks on the research of the medieval topography of Székesfehérvár]. Alba Regia 12 (1972) 261-267.

= A. KRALOVÁNSZKY: Újabb adatok Veszprém és Székesfehérvár településtörténetéhez (Neue Angaben zur Siedlungsgeschichte von Veszprém und Székesfehérvár). VMMK 17 (1984) 189-207.

= M. Molnár-L. RinyU-R. Janovics-I. Major-M. Veres: Az új debreceni C-14 laboratórium bemutatása (Introduction of the new AMS C-14 laboratory in Debrecen). Archeometriai Mühely 9 (2012) 147-160.

= M. Molnár-R. Janovics-I. Major-J. Orsovszki-R. GöncZi-M. Veres-A. G. Leonard-S. M. Castle-T. E. Lange-L. Wacker-I. Hajdas-A. J. T. Jull: Status report of the new AMS C-14 sample preparation lab of the Hertelendi Laboratory of Environmental Studies, Debrecen, Hungary. Radiocarbon 55 (2013) 665-676.

= M. MolnÁR-L. RinYU-M. VereS-M. SEILER-L. WACKER-H-A. Synal: EnvironMICADAS: a mini 14C-AMS with enhanced gas ion source interface in the Hertelendi Laboratory of Environmental Studies (HEKAL), Hungary. Radiocarbon 55 (2013) 338-344.

= A. Morgós: Faanyagok kormeghatározása - dendrokronológia és a magyarországi helyzet - Dating of wood - Dendrochronology and the situation of dendrochronology in Hungary. In: Az erdó és a fa régészete és néprajza - kézmüvesipar-történeti megközelítésben (Archaeology and Ethnography of Forest and Wood - In approximation of handicraft history). Ed.: J. Gömöri. Sopron 2007, 31-88.

= L. NAGY: Székesfehérvár későközépkori topográfiája (Die spätmittelalterliche Topographie von Stuhlweissenburg). In: Székesfehérvár évszázadai. 2.: Középkor. Ed.: A. Kralovánszky. Székesfehérvár 1972, 199-214.

= P. NIEWÖHNER: Archäologie und die „,Dunklen Jahrhunderte” im byzantinischen Anatolien. In: PostRoman Towns, Trade and Settlement in Europe and Byzantium. 2.: Byzantium, Pliska and the Balkans. Ed.: J. Henning. Berlin-New York 2007, 119-158.

= P. NiEwÖHNER: Byzantinische Stadtmauern in Anatolien. Vom Statussymbol zum Bollwerk gegen die Araber. In: Aktuelle Forschungen zur Konstruktion, Funktion und Semantik Antiker Stadtbefestigungen. Hrsg.: J. Lorentzen, F. Pirson, P. Schneider, U. Wulf-Rheidt. Istanbul 2010, 239-260.

$=\mathrm{G}$. W. PEARSON: Precise calendrical dating of know growth-period samples using a "curve fitting" technique. Radiocarbon 28 (1986) 292-299.

$=$ H. C. PEYER: Die Stadmauer in der Geschichte. In: Stadt- und Landmauern. 1.: Beiträge zum Stand der Forschung. Zürich 1995, 9-14.

= O. Prokop-T. Kolář-U. BÜntgen-J. KYnCl-T. Kyncl-M. BošEla-M. Choma-P. Barta-M. RYBNÍČEK: On the palaeoclimatic potential of a millennium-long oak ring width chronology from Slovakia. Dendrochronologia 40 (2016) 93-101.

= O. Prokop-T. KolÁř-T. KYNCL-M. RyBníčEK: Updating the Czech millennia-long oak tree-ring width chronology. Tree-Ring Research 73 (2017) 47-52.

$=$ P. RABB: Fejezetek az esztergomi Várhegy középkori épületeinek utóéletéböl (Chapters from the afterlife of medieval castle in Esztergom). Építés- Építészettudomány 32 (2004) 87-135.

$=$ P. RABB: Városi védmüvek a középkori Magyarországon [The ramparts of the towns in the medieval Hungary]. PhD diss. [Manuscript, Budapest] 2005.

= P. J. Reimer-E. Bard-A. Bayliss-J. W. Beck-P. G. Blackwell-C. Bronk Ramsey-P. M.

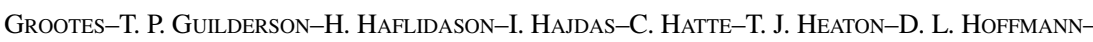
A. G. Hogg-K. A. Hughen-K. F. Kaiser-B. Kromer-S. W. Manning-M. NiU-R. W. Reimer-D. A. Richards-E. M. Scott-J. R. Southon-R. A. Staff-C. S. M. Turney-J. van der Plicht: IntCal13 and Marine 13 radiocarbon age calibration curves 0-50,000 years cal BP. Radiocarbon 55/4 (2013) 1869-1887.

= F. RINN: TSAP reference manual. 2005 .

= L. Rinyu-M. Molnár-I. Major-T. Nagy-M. Veres-Á. Kimák-L. Wacker-H. A. Synal: Optimization of sealed tube graphitization method for environmental C-14 studies using MICADAS. Nuclear Instruments and Methods in Physics Research Section B: Beam Interactions with Materials and Atoms 294 (2013) 270-275.

= GY. SÁNDORFI: A magyar várépítészet korai szakaszáról, irodalmi adatok és terepbejárások alapján (Über die Frühphase des ungarischen Burgbaues aufgrund von literarischen Angaben und Geländebegehungen). ArchÉrt 106 (1979/2) 244-254.

= GY. SIKLÓsı: Adattár Székesfehérvár középkori és törökkori építészetéről [Databank of the Medieval and Ottoman-Age Architecture of Székesfehérvár]. Székesfehérvár 1990. 
SIKLÓSI 1999

SIKLÓSI 2013

STOKES -SMILEY 1968 STUIVER-POLACH 1977 SzÜCSI 2015

SZÜCSI 2016

VERESS-SIKLÓSI 1990

ZOLNAY 1983

ZsOLDOS 2010

ZsOLDOS-THOROCZKAY-KISS 2016
= Gy. SIKLÓsI: Die mittelalterlichen Wehranlagen, Burg- und Stadtmauern von Székesfehérvár. Budapest 1999.

= Gy. SIKLÓsI: A törökkori Székesfehérvár [Székesfehérvár during the Ottoman Age]. Székesfehérvár 2013.

= M. A. Stokes-T. L. SmiLey: Introduction to Tree-Ring Dating. Chicago 1968.

= M. Stuiver-H. A. Polach: Reporting of C-14 data-Discussion. Radiocarbon 19 (1977) 355-363.

= F. SzÜCSI: Székesfehérvár belvárosának északi védművei. Új adatok a Fő utca és környéke rehabilitáció régészeti feltárásaiból (Die nördlichen Wehranlagen der Innenstadt von Székesfehérvár. Neue Daten der archäologischen Ausgrabungen von Fő utca und ihrer Gegend). In: Fiatal Középkoros Régészek VI. Konferenciájának Tanulmánykötete. Eds: Cs. Szőllősy, K. Pokrovenszki. Székesfehérvár 2015.

= F. SzÜCsI: Székesfehérvár, Jókai Mór u. 12. Tervásatás [Székesfehérvár, 12 Jókai Mór St. Research excavation]. Alba Regia 44 (2016) 187.

= Cs. D. VERESS-Gy. SIKLÓsI: Székesfehérvár a királyok városa [Székesfehérvár, the Town of Kings]. Budapest 1990.

= L. ZoLnAY: A középkori Esztergom [Medieval Esztergom]. Budapest 1983.

= A. Zsoldos: Korai vármegyéink az újabb történeti kutatások fényében [Our early historic counties in the light of the new historical researches]. Castrum. A Castrum Bene Egyesület Hírlevele 11/1 (2010), 5-13.

= A. Zsoldos-G. THOROCZKAY-G. KISs: Székesfehérvár története az Árpád-korban - The History of Székesfehérvár in the Age of the Árpád Dynasty. Székesfehérvár 2016. 
